\title{
Mencari Kebahagiaan Di Panti Asuhan
}

\author{
Indah Damayanti ${ }^{1}$, Don Ozzy Rihhandini ${ }^{2}$ \\ ${ }^{1}$ Fakultas Psikologi, Universitas Islam Negeri Sultan Syarif Kasim Riau \\ ${ }^{2}$ Fakultas Psikologi, Universitas Indonesia \\ indah.damayanti1785@gmail.com
}

\begin{abstract}
Abstrak
Kasih sayang dan rasa aman adalah hak setiap anak. Akan tetapi, tidak semua anak beruntung memiliki orangtua dan keluarga yang utuh. Sebagian mereka harus mengalami kehilangan orangtua di masa kanak-kanak, dan tidak memiliki rumah atau keluarga yang mengasuh, sehingga mereka terpaksa tinggal di panti asuhan. Penelitian ini merupakan studi kualitatif komparatif untuk melihat gambaran kebahagiaan pada anak-anak asuh di Kota Pekanbaru dan Padang dan membandingkan kebahagiaan anak-anak asuh panti di kedua kota tersebut. Peneliti melakukan wawancara dan observasi terhadap 18 (delapan belas) anak asuh pada 3 (tiga) panti asuhan di Padang dan 3 (tiga) panti asuhan di Pekanbaru. Hasil penelitian menunjukkan tidak terdapat perbedaan antara kebahagiaan anak asuh di kota Pekanbaru dan kebahagiaan anak asuh di kota Padang. Faktor-faktor kebahagiaan yang ditemukan ialah berkumpul dan berjumpa dengan keluarga, bermain dan bercanda dengan teman, memiliki harapan dan cita-cita, mengikuti perlombaan sesuai kemampuan. Kesimpulan, anak-anak di panti asuhan merasa relatif bahagia hidup di panti karena bersama teman-teman, akan tetapi mereka merasa lebih bahagia apabila mereka dapat berkumpul bersama dengan keluarga.
\end{abstract}

Kata kunci: anak panti asuhan; kebahagiaan

\begin{abstract}
Love and security are the rights of every child. However, not all children are lucky to have complete parents and families. Some of them have experienced the loss of their parents in childhood, and do not have a home or family to care for, so they are forced to live in orphanages. This research is a comparative qualitative study to see the picture of happiness in foster children in Pekanbaru and Padang City and to compare the happiness of the children in orphanages in the two cities. Researchers conducted interviews and observations on 18 (eighteen) orphanages in 3 (three) orphanages in Padang and 3 (three) orphanages in Pekanbaru. The results showed that there was no difference between the happiness of foster children in the city of Pekanbaru and the happiness of foster children in the city of Padang. The happiness factors found were gathering and meeting family, playing and joking with friends, having hopes and dreams, participating in competitions according to one's ability. In conclusion, the children in the orphanage feel relatively happy living in the orphanage because they are with friends, but they feel happier if they can gather together with their families.
\end{abstract}

Keywords: happiness; orphans 


\section{Pendahuluan}

Anak merupakan karunia Tuhan Yang Maha Esa yang harus dilindungi dan diperhatikan sebaik mungkin oleh seluruh lapisan masyarakat. Keluarga sebagai unit terkecil dari masyarakat, berperan besar dalam hal menjaga anak melalui pemenuhan kebutuhan dasar anak. Terpenuhinya kebutuhan dasar akan menjadikan anak individu yang sehat secara fisik maupun psikologis.

Brazelton dan Greenspan (Andresen, 2010) membagi kebutuhan utama anak menjadi beberapa hal yakni kebutuhan hubungan kasih sayang yang konstan, kebutuhan akan keamanan, kebutuhan akan pengalaman individual, kebutuhan pengalaman yang sesuai dengan tahapan perkembangan, kebutuhan adanya dukungan, serta kebutuhan akan rasa aman untuk masa depan. Orang tua berperan penting dalam proses pemenuhan kebutuhan dasar anak agar dapat tumbuh dan berkembang. Hurlock (2002) menyatakan bahwa salah satu sumbangan orang tua pada perkembangan anak yakni sebagai orang yang dapat diandalkan dalam memenuhi kebutuhan fisik dan psikologis anak. Namun pada kenyataannya, tidak semua anak mendapatkan pengasuhan oleh orangtua. Beberapa anak terpisah dari keluarganya karena suatu alasan seperti menjadi yatim, piatu atau yatim piatu, tidak memiliki sanak keluarga yang mampu atau mau mengasuh sehingga menjadi terlantar yang menyebabkan anak-anak tersebut dapat diasuh dalam lembaga pengasuhan seperti panti asuhan (Aesijah, 2014).

Panti sosial asuhan anak (PSSA) menurut Keputusan Menteri Sosial No. 50/HUK/2004 merupakan suatu lembaga yang mempunyai tugas memberikan bimbingan dan pelayanan bagi anak yatim, piatu, dan yatim piatu yang kurang mampu, terlantar, agar potensi dan kapasitas belajarnya pulih kembali dan dapat berkembang secara wajar (www. kemsos.go.id). Panti asuhan di Indonesia berjumlah sekitar 5.0008.000 panti (Schubert, 2015). Panti Asuhan di Kota Padang berjumlah kurang lebih 28 panti dengan anak asuh pada tahun 2017 kurang lebih 1.680 anak, menurut data yang diperoleh dari Dinas Sosial Kota Padang. Sedangkan jumlah panti asuhan di Kota Pekanbaru pada tahun 2017 menurut data Dinas Sosial Kota Pekanbaru kurang lebih 30 panti dengan jumlah anak asuh sekitar 2.250 orang anak. Kepala Seksi Kelembagaan Sosial Padang menuturkan hal yang melatar belakangi diasuhnya seorang anak di Panti Asuhan di Kota Padang adalah ketidakmampuan ekonomi orang tua (dhuafa), tidak adanya orang tua (yatim/piatu/yatim piatu), tidak adanya perawatan oleh orang tua dan kekerasan kepada anak yang berujung pada penelantaran anak. Hal yang sama juga disampaikan oleh Kepala Dinas Sosial Kota Pekanbaru.

Pengasuhan anak-anak di panti asuhan dapat menyebabkan anak mengalami berbagai resiko keterbatasan dan permasalahan, yakni dari segi fasilitas, lingkungan dan pengasuhan. Berdasarkan hasil wawancara peneliti dengan Ketua Badan Kerjasama Panti Asuhan Kota Padang, keterbatasan fasilitas yang terjadi di panti asuhan disebabkan karena kurangnya dana bantuan. Keterbatasan dalam sarana dan fasilitas ini dapat mempengaruhi kemampuan panti asuhan dalam menjamin perkembangan 
psikososial anak secara optimal (Dalimunthe, 2009). Pada Kota Pekanbaru, kurang lebih masalah yang ditemui sama.

Permasalahan lain dapat timbul dari lingkungan sekitar. Anak panti asuhan mendapatkan pandangan yang negatif dari lingkungan, seperti dicap sebagai "anak panti”, dikatakan miskin karena ketidakmampuan dalam mengikuti tren masa kini sehingga mendapat penolakan dari teman-teman di sekolahnya, dan adanya pengasuh panti asuhan yang mencemooh anak asuhnya karena tidak mampu mengerjakan tugas sekolahnya dengan baik (Prabadewi, 2014). Allport menyebutkan, efek dari pandangan seperti ini dapat menimbulkan beberapa masalah seperti rendahnya self-esteem, turunnya kesejahteraan psikologis dan kegagalan (Sarwono, 2009).

Keterbatasan lain yang paling menonjol adalah keterbatasan dari segi pengasuh. Sejauh pengamatan peneliti, jumlah antara pengasuh dengan anak asuh baik di Panti Asuhan di Kota Padang maupun di Kota Pekanbaru belum seimbang. Kepala Seksi Kelembagaan Sosial masing-masing kota menuturkan, kondisi beberapa panti asuhan masih belum memadai dalam hal sumber daya manusia dimana pengurus panti mencakup semua pekerjaan, baik dalam pengurusan sarana panti dan dalam hal pengasuhan anak. Ketua Badan Kerjasama Panti Asuhan (BKS PA) Kota Padang juga mendukung hal ini. Beliau mengatakan masih kurangnya pengasuh yang dapat mengayomi anak panti asuhan sebagaimana mestinya.

Sesuai Peraturan Menteri Sosial Republik Indonesia Nomor : 30 / Huk / 2011, rasio perbandingan antara pengasuh dengan anak agar pengawasan dapat efektif dan asuhan yang dilakukan lebih mendalam adalah 1: 5. Pada kenyataannya, peneliti menemukan di salah satu panti asuhan terdapat 2 orang pengasuh untuk 50 anak dan pada panti lainnya terdapat 1 orang pengasuh untuk 20 orang anak. Kurangnya jumlah pengasuh ini akan mempengaruhi keefektifan pengawasan dan pengasuhan yang akan berdampak pada tidak terpenuhinya kebutuhan psikis dan sosial anak atau anak dapat kekurangan perhatian dan kasih sayang dari pengasuh.

Gambaran komprehensif mengenai kualitas pengasuhan panti asuhan di Indonesia, diungkapkan melalui hasil penelitian Kementerian Sosial, Save the Children, dan UNICEF pada tahun 2006 dan 2007 terhadap 37 panti asuhan di 6 provinsi (www.kemsos.go.id). Panti asuhan di Indonesia lebih berfungsi sebagai lembaga penyedia akses pendidikan daripada sebagai lembaga alternatif terakhir pengasuhan anak yang tidak dapat diasuh oleh orangtua atau keluarganya. Sebanyak $90 \%$ anak yang tinggal di panti asuhan masih memiliki kedua orang tua dan dikirimkan ke panti asuhan dengan alasan utama untuk melanjutkan pendidikan. Hal ini mengakibatkan anak harus tinggal lama di panti asuhan sampai lulus SLTA dan harus menjalani pembinaan daripada pengasuhan yang seharusnya mereka terima dari orangtuanya. Peneliti menemukan hal yang serupa berdasarkan hasil wawancara dengan pengasuh, pengurus, kakak asuh dan anak asuh di tiga panti asuhan masing-masing di Kota Padang dan Pekanbaru. Hasil wawancara tersebut mengungkapkan hal yang diutamakan oleh panti asuhan adalah pendidikan dan akhlak. 
Berbagai permasalahan keterbatasan yang ada dapat menempatkan anak pada resiko mengalami masalah psikologis. Penelitian Aesijah (2014) mengenai permasalahan psikologis anak-anak asuh di panti asuhan menemukan bahwa anak yang tinggal di panti asuhan mengalami banyak masalah psikologis seperti kepribadian yang inferior, pasif, apatis, menarik diri, mudah putus asa, penuh dengan ketakutan dan kecemasan, lebih kaku dalam berhubungan sosial dengan orang lain dan penyesuaian sosialnya kurang memuaskan. Penelitian terkait mengenai anak panti asuhan telah dilakukan juga oleh Pilapil (2015) yang mengkaji mengenai well-being pada anak panti asuhan. Penelitian dengan subjek anak panti asuhan yang kehilangan salah satu atau kedua orangtua karena kematian akibat AIDS, menemukan bahwa anak panti asuhan tidak hanya tidak terpenuhi kebutuhan dasarnya tapi juga memiliki masalah internal yang dapat membahayakan kesehatan mental mereka.

Keterbatasan yang dialami oleh anak panti asuhan dapat menyebabkan anak mengalami hospitalism (Splitz dalam Prabadewi, 2014). Hospitalism yaitu tidak terpenuhinya kebutuhan akan kasih sayang atau afeksi sehingga terasing secara emosional. Banyak faktor yang menyebabkan keterasingan emosional tersebut, misalnya karena kurangnya perhatian dari pengasuh akibat keterbatasan tenaga pengasuh, kurangnya fasilitas fisik, terlalu ketatnya disiplin dan aturan yang dijalankan yang memungkinkan anak tersebut cenderung menampakkan sikap pendiam, pasif, kurang responsif terhadap orang lain dan merasa rendah diri, sehingga cenderung menarik diri dan lebih bersikap defensif dalam pergaulan (Prabadewi, 2014). Tidak terpenuhinya kebutuhan kasih sayang pada anak panti asuhan dapat berhubungan dengan ketidakbahagiaan karena individu yang bahagia memiliki karakteristik selfesteem yang positif, memiliki rasa optimis, terbuka dan memiliki kontrol atas diri (Myers, 1995).

Namun tidak semua anak asuh di panti asuhan mengalami permasalahan psikologis yang menyebabkan masalah ketidakbahagiaan seperti hasil penelitian yang telah dipaparkan. Penelitian yang dilakukan oleh Pilapil (2015) mengungkapkan subjek penelitian yakni anak panti asuhan di Filipina menilai diri mereka bahagia terlepas dari fakta bahwa mereka kekurangan banyak hal-hal penting dalam hidup mereka, yakni keluarga. Dengan keberanian, penilaian positif, keyakinan yang kuat dan realistis serta lingkungan yang mendukung, mereka mampu mencapai kepuasan dalam hidup.

Kebahagiaan atau happiness merupakan istilah yang sering digunakan secara bergantian dengan subjective well-being, istilah kebahagiaan digunakan karena lebih mudah dimengerti bahkan oleh individu yang masih kecil (Chaplin, 2009). Veenhoven (2006) mengemukakan bahwa kebahagiaan merupakan evaluasi mengenai hidup termasuk ekspektasi mengenai hidup atau secara singkat didefinisikan sebagai keseluruhan apresiasi terhadap diri atau seberapa suka individu dengan hidupnya. Sedangkan bagi anak, kebahagiaan tidak sepenuhnya merupakan pengalaman subjektif, tapi merupakan intersubjective space atau hubungan psikologis antara satu orang dengan yang lain (Thoilliez, 2011). Anak merasakan kebahagiaan dengan orang lain dan 
melalui orang lain. Pada masa anak-anak awal, hubungan intersubjektif ini lebih berpusat pada keluarga sedangkan pada masa anak-anak akhir muncul melalui pengakuan oleh teman sebaya. Keluarga dan teman menemani dan memberikan keamanan bagi anak.

Veenhoven (2006) dan Feldman (2008) menggambarkan kebahagiaan sebagai memiliki sikap positif terhadap kehidupan, dimana sepenuhnya dipengaruhi oleh aspek kognitif dan afektif. Diener (2004) mengemukakan bahwa aspek afektif berkaitan dengan emosi-emosi positif yang dirasakan oleh individu mencakup kegembiraan, perasaan suka cita, kebanggaan, kasih sayang, dan kepuasan. Sedangkan aspek kognitif berkaitan dengan kepuasan terhadap bagian-bagian kehidupan. Kepuasan terhadap bagian-bagian kehidupan mencakup kepuasan terhadap diri sendiri, keluarga, teman, kesehatan, keuangan, pekerjaan dan waktu luang.

Kebahagiaan merupakan salah satu bentuk emosi dimana salah satu komponen emosi adalah penilaian kognitif. Penilaian kognitif berperan dalam proses pembentukan dan membedakan emosi-emosi yang terjadi pada individu (Atkinson, 1990). Ketika mengalami suatu kejadian, individu akan menginterpretasikan situasi tergantung kepada tujuan dan kondisinya pada saat itu (penilaian kognitif). Hasil dari interpretasi ini merupakan suatu bentuk keyakinan baik positif maupun negatif seperti "saya menang lomba dan saya merasa bahagia" atau "saya gagal dalam tes dan saya merasa sedih" (Atkinson, 1990). Anak usia 5-12 tahun telah memiliki kematangan kognitif dan afektif yang memungkinkan dilakukannya studi mengenai emosi khususnya kebahagiaan (Berk dalam Holder, 2012). Selama masa kanak-kanak, perkembangan emosional dan kognitif dicapai termasuk kemampuan mengumpulkan informasi dari banyak sumber untuk membantu memahami dan menjelaskan cakupan luas dari emosi mereka dan emosi orang lain.

Pada anak-anak, kebahagiaan mereka dapat dilihat dari beberapa faktor yakni afek positif, kejadian penting dan situasi sehari-hari, aspirasi, talenta dan hubungan atau relationship (Thoilliez, 2011). Afek positif atau kepuasan terhadap diri merupakan persepsi subjektif individu terhadap kepuasan hidup secara keseluruhan. Penilaian pada afek positif berguna untuk melaporkan kepuasan hidup secara keseluruhan pada saat ini dan penilaian diukur melalui self-report. Afek positif berhubungan dengan seberapa bahagia anak terhadap kehidupannya (Thoilliez, 2011).

Faktor selanjutnya yaitu kejadian penting dan situasi sehari-hari (Thoilliez, 2011). Faktor ini bertujuan untuk mengetahui persepsi anak tentang kebahagiaan. Kejadian dan situasi sehari-hari berisi tentang kebahagiaan masa lalu dan masa kini, kejadian yang menyedihkan serta situasi sehari-hari yang membuat anak merasa bahagia atau sedih. Kejadian dan situasi sehari-hari berhubungan dengan memori anak mengenai kejadian yang membahagiakan dan yang tidak membahagiakan. Kejadian penting dan situasi sehari-hari ini mencakup beberapa faktor seperti keluarga, sahabat dan hubungan pertemanan, performansi di sekolah, pesta dan kejadian spesial, waktu luang dan kewajiban, sakit atau terluka dan moral serta nilai. 
Faktor selanjutnya yakni aspirasi dan talenta. Menurut hasil penelitian Thoilliez (2011) anak-anak cenderung memandang aspirasi sebagai jaminan untuk kebahagiaan mereka di masa depan. Aspirasi menurut hasil penelitian ini terbagi atas beberapa hal diantaranya harapan untuk bekerja, keamanan dan kontinuitas, serta pencapaian dibidang akademik. Aspirasi menunjukkan apa saja harapan di masa depan, seberapa bahagia atau sedih mereka memandang masa depan mereka ketika mereka dewasa.

Talenta menggambarkan hal-hal yang dikuasai anak. Berdasarkan penelitian oleh Thoilliez (2011), talenta merupakan faktor yang penting bagi kebahagiaan anak dan menggambarkan kesadaran anak terhadap kemampuannya menguasai hal tertentu dan memiliki talenta. Penelitian oleh Thoilliez (2011) menemukan bahwa anak-anak menilai mereka memiliki talenta pada suatu hal berdasarkan apresiasi dari orang dewasa seperti mendapatkan pujian. Talenta yang dinilai lebih oleh anak-anak sehingga dapat memberikan kebahagiaan dan kesedihan bagi mereka adalah perilaku (kemampuan sosial, perilaku merusak, dan tanggung jawab), kemampuan ateletik (berkaitan dengan kemampuan olahraga), prestasi sekolah, kemampuan artistik, kemampuan rekreasional, dan membantu pekerjaan dirumah.

Faktor terakhir yang menentukan kebahagiaan anak adalah hubungan atau relationship. Faktor ini bertujuan untuk mengetahui lingkungan yang dinilai lebih oleh anak untuk memberikan kebahagiaan bagi mereka. Pada penelitian Thoilliez (2011), faktor ini dinilai melalui empat situasi yakni keluarga, sekolah, teman, dan bermain. Faktor ini ditujukan agar anak dapat memberitahu apa yang mereka nilai sebagai pengalaman yang membahagiakan diantara dimensi-dimensi dalam kehidupannya.

Kebahagiaan pada anak-anak dapat memberikan berbagai dampak positif. Kebahagiaan berhubungan dengan kesehatan yang lebih baik dimana kebahagiaan dapat membuat imun bekerja dengan lebih baik. Kebahagiaan berhubungan juga dengan pola hidup sehat, dimana individu yang bahagia lebih memperhatikan berat badan mereka, lebih peka terhadap gejala penyakit dan memiliki coping yang lebih baik ketika menghadapi peritiwa yang mengancam. Selain itu kebahagiaan dapat meningkatkan level kreativitas, jangkauan atensi yang lebih luas dan dapat menghasilkan hubungan sosial yang lebih baik (Holder, 2012).

Berdasarkan paparan di atas, terlihat bahwa anak-anak asuh di panti asuhan, baik di Kota Pekanbaru maupun Padang mengalami permasalahan dari segi pengasuhan, fasilitas dan lingkungan yang dapat mempengaruhi kondisi psikologis anak khususnya kebahagiaan. Penelitian ini dilakukan untuk mengkaji lebih jauh mengenai gambaran kebahagiaan anak-anak di panti asuhan dengan membandingkan hasil penelitian pada Kota Padang dan Kota Pekanbaru.

\section{Metode}

\section{Desain Penelitian}


Penelitian ini ialah penelitian kualitatif komparatif. Penelitian kualitatif ialah penelitian yang bertujuan untuk menggambarkan suatu situasi, fenomena, masalah atau kejadian (Kumar, 1999). Sedangkan penelitian komparatif bertujuan membandingkan dua kondisi atau lebih untuk melihat persamaan dan perbedaan di antara keduanya (Arikunto, 1997). Penelitian ini mencoba memperoleh gambaran kebahagiaan anak asuh pada panti asuhan dan membandingkan (melihat persamaan dan perbedaan) gambaran kebahagian tersebut pada anak asuh di panti asuhan di Kota Pekanbaru dan Padang.

\section{Informan Penelitian}

Total jumlah informan pada penelitian ini ialah 18 orang, 9 orang dari panti asuhan di Pekanbaru dan 9 orang dari panti asuhan di Padang. Karakteristik informan adalah sebagai berikut :

1. Merupakan anak yatim atau piatu. Karakteristik ini ditentukan karena dengan tidak adanya salah satu orang tua, anak tidak memiliki orang yang sangat berpengaruh terhadap kebahagiaan dalam hidupnya.

2. Berusia 8-12 tahun atau berada pada periode anak-anak akhir, karena pada periode ini anak sudah bisa berpikir lebih logis dari periode sebelumnya, tidak lagi egosentris dan tahapan kognitif anak sudah memungkinkan untuk dilakukan wawancara.

3. Berjenis kelamin laki-laki dan perempuan.

4. Sudah dan sedang berada di panti asuhan kurang lebih 1 tahun. Anak asuh di panti asuhan membutuhkan waktu untuk beradaptasi. Kemampuan adaptasi setiap anak berbeda-beda. Jangka waktu satu tahun diambil peneliti karena anak sudah dianggap mampu beradaptasi dalam jangka waktu tersebut.

\section{Metode Pengambilan Data}

Pada penelitian ini peneliti menggunakan teknik wawancara, observasi dan visual. Penelitian ini menggunakan wawancara semi terstruktur. Jenis wawancara ini dipilih karena penelitian ini bertujuan untuk menemukan permasalahan secara lebih terbuka dimana informan dimintai pendapat dan ide-idenya (Sugiyono, 2008). Observasi dilakukan oleh peneliti untuk mendukung data yang didapatkan melalui wawancara. Observasi diarahkan pada kegiatan memperhatikan secara akurat, mencatat fenomena yang mucul dan mempertimbangkan hubungan antar aspek dalam fenomena tersebut (Poerwandari, 1998). Peneliti menggunakan media visual berupa gambar untuk memperdalam hasil wawancara yang telah dilakukan. Penggunaan media gambar ini disebut sebagai metode collage oleh Chaplin dan John (Chaplin, 2009). Media gambar berisi item-item yang merupakan sumber kebahagiaan anak berdasarkan hasil wawancara yang telah dilakukan peneliti. Anak diminta memilih, menyusun dan menceritakan kembali mengenai item-item yang dipilihnya. Hasil dari pemilihan dan deskripsi anak pada gambar akan disesuaikan dengan hasil wawancara. 
Dalam pengumpulan data penelitian, peneliti menggunakan beberapa alat bantu guna menghindari kesalahan dan kehilangan data penelitian. Alat bantu yang digunakan dalam penelitian ini adalah alat perekam, buku catatan serta guideline wawancara dan observasi, serta pulpen. Sebelum dilakukannya wawancara, peneliti terlebih dahulu meminta izin kepada informan untuk menggunakan alat perekam dan menjelaskan mengenai topik wawancara secara ringkas dan jelas.

\section{Hasil}

Berdasarkan tema-tema yang ditemukan dari informan, peneliti mengintegrasikannya ke dalam sebuah deskrispi. Tema-tema yang ditemukan pada masing-masing informan secara umum merupakan hal yang sama. Pengalaman masingmasing informan saat pertama kali tinggal di panti asuhan adalah sedih ketika berpisah dari keluarga. Seorang informan, J, pertama kali masuk panti asuhan dibawa oleh neneknya dengan alasan untuk menghindari pengaruh buruk di kampungnya. Saat pertama masuk ke panti asuhan J mengaku sering sedih namun hal itu mulai berubah ketika ia sudah memiliki banyak teman. Hal yang sama dirasakan oleh F. Ia juga sedih saat pertama tinggal di panti asuhan. Namun hal itu berubah ketika ia sudah memiliki teman dan ia sangat senang ketika diadakannya acara jalan-jalan dengan pihak panti asuhan. Sedangkan informan K mengaku tidak memiliki masalah. Hal ini dikarenakan ia masih memiliki sanak saudara yang tinggal bersama di panti asuhan.

Bagi masing-masing informan, hal yang membuat mereka bahagia di panti asuhan adalah teman. Bersama teman mereka bermain, bercanda tawa, bercerita dan saling mendukung satu sama lain. Mereka juga menyukai dan merasa senang ketika diadakan acara jalan-jalan oleh pihak panti asuhan. Selain hal tersebut, keluarga tetap menjadi bagian dari kebahagiaan mereka. Bagi mereka, berjumpa dan berkumpul bersama keluarga merupakan hal yang membahagiakan.

Hal lain yang membuat anak asuh panti asuhan merasa bahagia adalah prestasi dan perlombaan di sekolah maupun di panti asuhan. Perlombaan yang diikuti sesuai dengan bidang yang mereka kuasai dan senangi. Prestasi di sekolah seperti mendapat juara kelas membuat mereka merasa senang. Melalui prestasi-prestasi tersebut mereka memperoleh piagam dan sejumlah uang yang kemudian ditabung untuk persiapan di masa depan. Semua informan memiliki harapan untuk berbahagia dimasa depan. Masing-masing informan memiliki harapan atau cita-cita yang berbeda. Melalui citacita tersebut mereka berharap dapat menjadi individu yang berbahagia.

\section{Pembahasan}

Pada masa anak-anak kebahagiaan merupakan hal yang penting karena dapat mempengaruhi beberapa aspek dalam kehidupan di masa dewasa seperti kesehatan, peningkatan pada level kreativitas, jangkauan atensi dan kesuksesan dalam bekerja dan sekolah. Menurut Seligman (O'Rourke, 2010), akar dari kebahagiaan pada masa dewasa 
dibentuk dari masa kecil.

Anak asuh panti asuhan berasal dari berbagai rentang usia dan berbagai latar belakang. Pada anak-anak yang diasuh di panti asuhan, kematian orang tua, perceraian dan masalah ekonomi serta penelantaran dapat menyebabkan mereka tidak dapat merasakan kebahagiaan sebagaimana seharusnya. Panti asuhan yang memiliki peranan sebagai pengganti orang tua dalam menjaga tumbuh kembang anak tidak luput dari berbagai keterbatasan yang menempatkan anak pada resiko terjadinya masalah-masalah psikologis salah satunya masalah kebahagiaan.

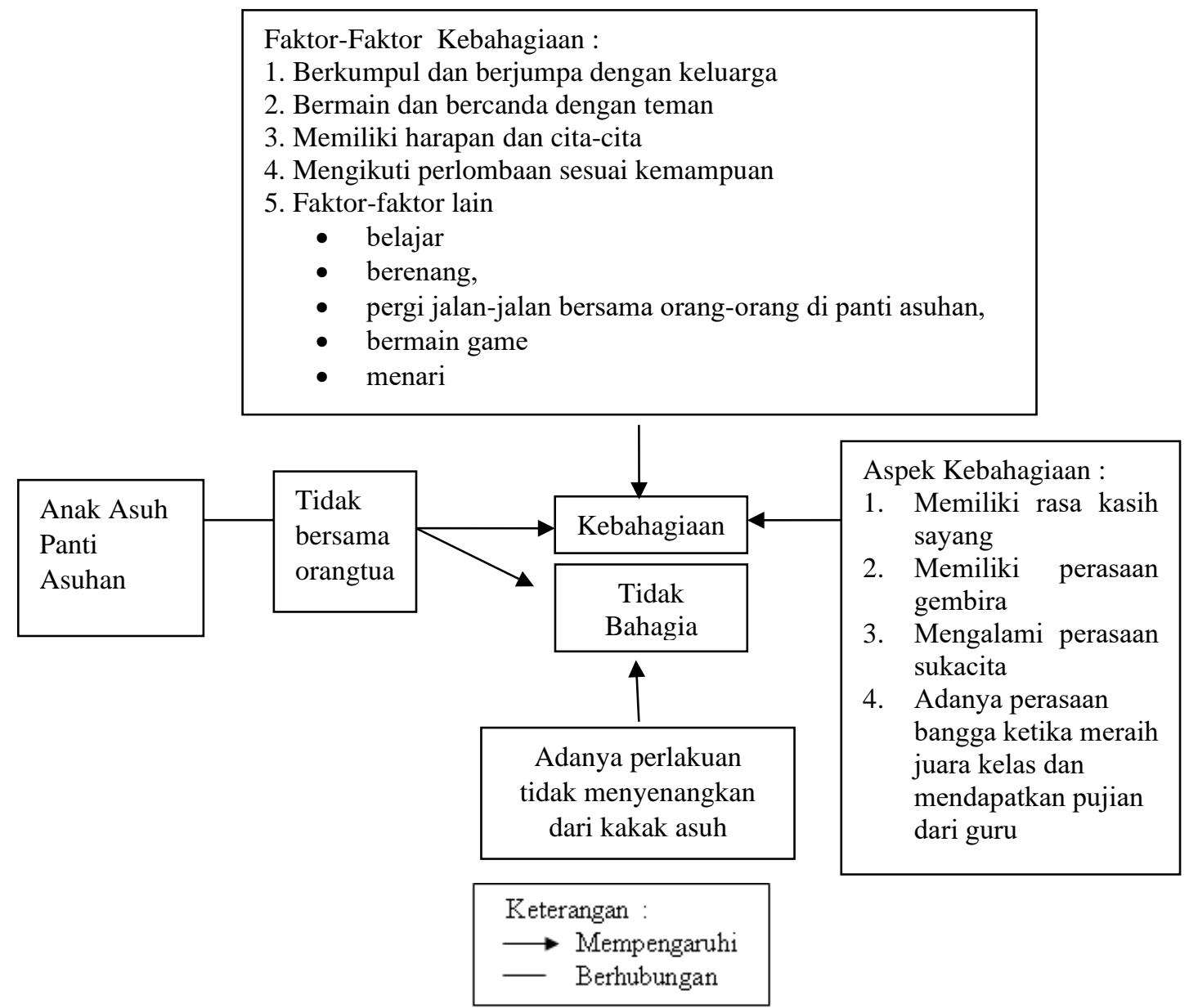

Gambar 1.Skema Dinamika Kebahagiaan

Kebahagiaan didefenisikan sebagai keseluruhan evaluasi mengenai hidup termasuk semua kriteria yang berada di dalam pemikiran individu seperti bagaimana rasanya hidup yang baik, sejauh mana hidup sudah mencapai ekspektasi, bagaimana hidup yang menyenangkan dapat dicapai dan sebagainya atau secara singkat didefinisikan sebagai keseluruhan apresiasi terhadap diri atau seberapa suka individu dengan hidupnya (Veenhoven, 2006). Bagi anak-anak, kebahagiaan tidak sepenuhnya merupakan pengalaman subjektif, tapi merupakan intersubjective space atau hubungan psikologis antara satu orang dengan yang lain (Thoilliez, 2011). 
Informan dalam penelitian ini merupakan anak asuh di panti asuhan di kota Pekanbaru dan Padang. Mereka berasal dari latar belakang yang berbeda yakni yatim, piatu, dan yatim piatu. Informan penelitian mengaku mengalami perasaan sedih ketika baru pertama kali tinggal di panti asuhan. Hal itu mulai berangsur-angsur berubah ketika mereka sudah memiliki teman bermain. Bagi masing-masing informan, kebahagiaan diartikan sebagai perasaan senang. Senang dapat muncul ketika mereka bermain bersama teman, mendapatkan juara atau melakukan hal yang mereka senangi.

Bagi masing-masing informan, hal yang membuat mereka merasa bahagia berhubungan dengan teman dan keluarga. Teman sebagai orang yang paling dekat dengan mereka sehari-hari dinilai sebagai sumber kebahagiaan karena bersama teman mereka tidak lagi merasa sedih karena harus tinggal terpisah dari keluarga. Bersama teman mereka bermain dan melakukan hal-hal yang mereka senangi. Bersama teman mereka juga saling bercanda tawa. Selain teman, informan juga menilai keluarga sebagai sumber kebahagiaan. Berjumpa atau berkumpul bersama keluarga saat liburan atau saat kunjungan panti asuhan membuat mereka merasa senang.

Berdasarkan penelitian oleh Thoilliez (2011), anak-anak cenderung memandang aspirasi sebagai jaminan untuk kebahagiaan mereka di masa depan. Aspirasi menunjukkan apa saja harapan anak di masa depan, seberapa bahagia/sedih mereka memandang masa depan ketika mereka dewasa. Masing-masing informan memiliki harapan untuk dapat menjadi individu yang berbahagia dimasa depan. Mereka memiliki harapan atau cita-cita untuk bekerja dan membahagiakan keluarga. Informan juga menuturkan mereka memiliki hal yang mereka kuasai baik dalam bidang akademik ataupun non akademik seperti bidang olahraga. Kemampuan tersebut mereka sadari dan hal tersebut dimanfaatkan untuk mengikuti perlombaan.

Faktor-faktor lain yang dapat membuat anak asuh merasakan kebahagiaan di panti asuhan adalah saat acara jalan-jalan dengan pihak panti asuhan. Bagi mereka hal itu merupakan sesuatu yang membahagiakan karena mereka dapat berkumpul dan bermain bersama teman-teman di lingkungan luar panti asuhan. Acara ini dilangsungkan secara rutin oleh pihak panti asuhan sebanyak satu kali dalam setahun dan diadakan setelah anak asuh selesai ujian akhir semester 2. Acara jalan-jalan memiliki tujuan tempat yang berbeda-beda tiap tahunnya. Acara ini berlangsung selama satu hari dan kemudian mereka bersama-sama pulang ke panti asuhan.

Selain dari faktor-faktor tersebut diatas, anak asuh panti asuhan juga merasakan beberapa aspek kebahagiaan yakni perasaan kasih sayang, sukacita, gembira dan bangga. Perasaan-perasaan tersebut muncul karena interaksi mereka dengan teman atau dengan guru disekolah. Bersama teman, keseharian anak asuh adalah bermain dan bercanda tawa. Melalui hal tersebut anak dapat merasakan perasaan gembira dan kasih sayang. Anak asuh tidak sungkan untuk bermain bersama dan berbagi mainan dengan teman sebaya atau dengan teman dengan usia yang lebih kecil. Prestasi-prestasi yang mereka peroleh di sekolah melalui perlombaan akademik maupun non akademik membuat mereka merasakan perasaan sukacita dan bangga. Perasaan sukacita muncul 
ketika mereka memperoleh juara dari perlombaan yang tidak mereka duga. Sedangkan perasaan bangga muncul ketika mereka mendapatkan pujian dari guru di sekolah.

Anak asuh dalam penelitian ini cenderung merasakan kebahagiaan ketika mereka tinggal di panti asuhan. Adanya teman merupakan sumber utama kebahagiaan mereka ketika tinggal di panti asuhan. Akan tetapi, terkadang mereka merasakan sedih ketika teringat dengan keluarga. Kunjungan keluarga atau saat pulang kampung merupakan sumber kebahagiaan bagi anak asuh karena mereka dapat berjumpa dan berkumpul kembali dengan keluarganya.

\section{Kesimpulan}

Berdasarkan penelitian, terlihat bahwa anak asuh panti asuhan baik di Kota Pekanbaru ataupun Padang cenderung merasakan kebahagiaan. Kebahagiaan oleh anak asuh panti asuhan diartikan sebagai suatu perasaan senang. Sumber utama kebahagiaan bagi anak asuh panti asuhan terkait dengan teman dan keluarga. Teman merupakan individu yang dekat dengan anak dalam kesehariannya. Bersama teman mereka melakukan berbagai hal bersama seperti bermain dan bercanda tawa bersama.

Selain teman, bagi anak asuh keluarga juga merupakan sumber kebahagiaan. Masing-masing informan pada penelitian ini tidak lagi memiliki keluarga yang lengkap yakni yatim, piatu dan yatim piatu. Kondisi keluarga tersebut memaksa mereka untuk tinggal di panti asuhan. Perpisahan dengan keluarga dianggap sebagai suatu hal yang menyedihkan bagi mereka ketika mereka pertama kali tinggal di panti asuhan. Kunjungan keluarga atau saat pulang kampung merupakan hal yang membahagiakan bagi anak karena mereka dapat berjumpa dan berkumpul bersama keluarga.

Anak asuh juga merasakan kebahagiaan melalui hal lain seperti mendapatkan prestasi melalui perlombaan akademik atau non akademik. Anak asuh menyadari potensi mereka yang kemudian mereka manfaatkan untuk mengikuti beberapa perlombaan. Hal lain yang mampu membuat anak asuh merasakan kebahagiaan selama tinggal di panti asuhan adalah saat acara jalan-jalan yang diadakan oleh pihak panti asuhan.

Anak asuh di panti asuhan merasakan beberapa pengalaman emosi positif dari keseharian mereka yang mendukung timbulnya perasaan kebahagiaan. Emosi positif tersebut mencakup perasaan kasih sayang, sukacita, gembira dan bangga. Perasaan kasih sayang muncul ketika mereka bermain bersama teman yakni mereka mau berbagi mainan kepada sebaya ataupun kepada anak asuh yang memiliki usia lebih kecil. Anak asuh juga merasakan perasaan sukacita dan bangga ketika mereka memperoleh juara dalam perlombaan ataupun juara kelas serta mendapatkan pujian dari guru disekolah. Anak asuh dalam kesehariannya bermain dan bercanda tawa dengan teman dimana hal ini dapat memunculkan perasaan gembira. 
Dengan demikian dapat disimpulkan, anak asuh pada penelitian ini cenderung merasakan kebahagiaan ketika mereka tinggal dipanti asuhan. Pada penelitian ini yang menjadi sumber utama kebahagiaan anak asuh adalah teman dan keluarga.

Masih banyak kekurangan dalam penelitian ini, untuk penelitian selanjutnya peneliti menyarankan untuk menambah informan dengan latar belakang yang berbeda yakni mencakup dhuafa. Untuk penelitian selanjutnya, peneliti juga menyarankan lebih memperdalam penggalian informasi mengenai penyebab timbulnya kebahagiaan pada anak. Saran bagi pengasuh pada panti asuhan untuk meningkatkan dukungan bagi anak agar anak dapat merasakan kebahagiaan di panti asuhan. Panti asuhan juga disarankan untuk menambah jumlah pengasuh agar kebutuhan tiap anak dapat terpenuhi dan adanya kontrol terhadap perilaku anak asuh.

Adapun untuk pemerintah, pihak-pihak terkait kesejahteraan anak, dan masyarakat diharapkan dapat memahami pentingnya kebahagiaan di masa anak-anak. Hendaknya pemerintah, pihak-pihak terkait kesejahteraan anak dan masyarakat memberikan fasilitas yang maksimal terhadap anak asuh di panti asuhan agar mereka mampu mengembangkan potensi yang dimiliki lebih baik lagi.

\section{Referensi}

Aesijah, S. (2014). Pengaruh pelatihan regulasi emosi terhadap kebahagiaan remaja panti asuhan yatim piatu. Tesis. Surakarta: Universitas Muhammadiyah Surakarta.

Andresen, S., dkk. (2010). Children and the good life: New challenges for research on children. New York : Springer.

Androe, G. (2009). Gambaran self esteem remaja yang tinggal di panti asuhan. Jurnal psikologi 7(2), 52-70.

Arif, I.S. (2016). Psikologi psositif : Pendekatan saintifik menuju kebahagiaan. Jakarta : Gramedia.

Atkinson, R.L., dkk. (1990). Introduction to psychology $10^{\text {th }}$ edition. USA : Harcourt Brace Jovanovich Inc.

Carr, A.(2004). Positive psychology : The science of happiness and human strengths. New York : Brunner-Routledge

Chaplin, L.N. (2009). Please may I have a bike? Better yet, may I have a hug? An examination of children's and adolecents' happiness. Journal Happiness Study, $10,541-562$.

Creswell, J.W. (2010). Research design : Pendekatan kualitatif, kuantitatif dan mixed. Yogyakarta : Pustaka Pelajar.

Collin, C., dkk. (2012). The psychology book. New York : DK Publishing.

Dalimunthe, K.L. (2009). Kajian mengenai kondisi psikososial anak yang dibesarkan di panti asuhan. Bandung : Universitas Padjajaran, Fakultas Psikologi. 
Feldman, F. (2008). Whole life satisfaction concepts of happiness. Theoria, 74 (3), 219238.

Hasbiansyah, O. (2008). Pendekatan feneomenologi : Pengantar praktik penelitian dalam ilmu sosial dan komunikasi. MediaTor, 9 (1), 163-180.

Holder, M. D. (2012). Happiness in children : Measurements, correlates, and enhancement of positive subjective well-being. London : Springer.

Holder, M. D \& Klassen, A. (2010). Temperament and happiness in children. Journal Happiness Study, 11, 419-439.

Hurlock, E.B. (2002). Perkembangan anak jilid 1 edisi keenam. Jakarta: Erlangga.

Jensen, M. (2014, Februari). Smile as feedback expressions in interpersonal communication : A first acquitance context. Makalah dipresentasikan pada SSKKII-publications Technical Report, Sweden.

Karim, A. (2011). Data Panti Asuhan Yatim Piatu. Jakarta : Kementerian Agama Republik Indonesia.

Kumar, R.(1996). Research methodology: astep by step guide for beginners. London: Sage Publications, Inc.

Kurniawati, Y., Hong, J. (2015). May I have some more time to play, please?: An exploration of Javanese Indonesian children's happiness. Research on Humanities and Social Sciences, 5 (12), 69-74.

Lapau, B. (2013). Metode penelitian kesehatan. Jakarta : Yayasan Pustaka Obor Indonesia

Moustakas, C.E. (1994). Phenomenological research methtods. California: Sage Publications Inc.

Myers, D.G., \& Diener, E. (1995). Who is happy?. Psychological Science, 6(1)

O'Rourke, J. \& Martin, C. (2010). Lucky to be happy : A study of happiness in Australian primary students. Australian Journal of educational and developmental psychology, 10, 94-107.

Papalia, D.E., Feldman, R.D., \& Olds, S.W. (2008). Human development $\left(11^{\text {th }}\right.$ ed). McGraw Hill Higher Education.

Pilapil, A. C. D. (2015). Unfolding the psychological well-being of orphans : A qualitative study of Filipino children in an orphanage. International Journal of Social Science and Humanities Research, 3 (3), 404-415.

Poerwandari. E. K. (1998). Pendekatan kualitatif dalam penelitian psikologi. Jakarta : LPSP3 UI

Prabadewi. K.D.L., \& Putu, N.W. (2014). Hubungan konsep diri akademik dengan motivasi berprestasi pada remaja awal yang tinggal di panti asuhan di Denpasar. Jurnal Psikologi Udayana, 1(2), 261-270. 
Santrock, J. W. (2011). Perkembangan masa hidup edisi ketigabelas jilid 1. Jakarta : Erlangga.

Sarwono, S., dkk. (2009). Psikologi Sosial. Jakarta : Salemba Humanika.

Schubert, B., Rusyidi, B., Pratiwi, A.P., \& Halim, M.A. (2015). Penilaian cepat program kesejahteraan sosial anak (PKSA). Jakarta : Kementerian Sosial Republik Indonesia.

Seligman, M.E.P. (2002). Authentic happiness : Menciptakan kebahagiaan dengan psikologi positif. Diterjemahkan oleh Eva Y.N. Bandung: Mizan.

Shaffer, D. R. (1985). Development psychology. California: Wodsworth Publishing Company, Inc.

Sugiyono. (2008). Metode penelitian kuantitatif, kualitatif dan $r \& d$. Bandung: Alfabeta

Thoilliez, B. (2011). How to grow up happy : An exploratory study on the meaning of happiness from children's voices. Child Indicators Research, 4(2), 323-351.

Veenhoven, R. (2006). .Healthy happiness : Effect of happiness on physical health and the consequences for preventive health care. Journal of Happiness Studies, 9 , 449-469.

Yusuf, A. M. (2014). Metode penelitian : kuantitatif, kualitatif, dan penelitian gabungan edisi pertama. Jakarta : Kencana. 